\title{
Location-Inventory-Routing Model with Considering Urban Road Networks
}

\author{
Nova Indah Saragih ${ }^{1}(\mathbb{D})$, Senator Nur Bahagia ${ }^{1}$, Suprayogi Suprayogi ${ }^{2}$ (D) Ibnu Syabri ${ }^{3}$ \\ ${ }^{1}$ Department of Industrial Engineering, Telkom University (Indonesia) \\ ${ }^{2}$ Faculty of Industrial Technology, Bandung Institute of Technology (Indonesia) \\ ${ }^{3}$ School of Architecture, Planning, and Policy Development, Bandung Institute of Technology (Indonesia) \\ novaindab@telkomuniversity.ac.id,senator@mail.ti.itb.ac.id,yogi@mail.ti.itb.ac.id,syabri@pl.itb.ac.id
}

Received: April 2021

Accepted: September 2021

\section{Abstract:}

Purpose: To develop LIRP (location-inventory-routing problem) model with considering multiple links and solve it using method of heuristic based on algorithm of simulated annealing. Method of heuristic for the LIRP model is applied in city of Jakarta to improve effectiveness and efficiency of the food supply chain.

Design/methodology/approach: The LIRP model is developed using main references. To solve the model, this paper develops two methods, namely method of optimal and method of heuristic. Computational experiments are performed to obtain the efficiency of the method of heuristic. New design of food supply chain is resulted from the application of the method of heuristic in city of Jakarta.

Findings: The new design of food supply chain resulted from the application of LIRP model in city of Jakarta reduces total cost by $18 \%$, increases availability from $76 \%$ to $95 \%$, and reduces the number of vehicles by $73 \%$. This paper also shows that distance is not the only consideration to decide the traversed links in cities.

Research limitations/implications: Average gap between method of heuristic and method of optimal in terms of total cost is $3.1 \%$.

Practical implications: Government of city of Jakarta can improve effectiveness and efficiency of the food supply chain by implementing the LIRP model.

Social implications: Citizens of Jakarta are well provided with their needs of vegetables and fruits.

Originality/value: The first LIRP model that considers multiple links to represent road networks in cities. The LIRP model developed in this paper consists of probabilistic demands, multi products, and multi echelons. Traditional markets, UCCs (urban consolidation centers) and province of suppliers are the places where decisions of inventory made.

Keywords: LIRP model, cost of congestion, road networks, method of heuristic, simulated annealing

\section{To cite this article:}

Saragih, N.I., Bahagia, S.N., Suprayogi, S., \& Syabri, I. (2021). Location-inventory-routing model with considering urban road networks. Journal of Industrial Engineering and Management, 14(4), 830-849. https://doi.org/10.3926/jiem.3557 


\section{Introduction}

There are multiple road networks that connect places in urban areas. To apply the model of LIRP (location-inventory-routing problem) in urban areas, one needs to consider multiple links to represent the road networks. There is no model of LIRP that considers multiple links. It can be known from literature review of LIRP that has been done in Table 1; therefore, there is a research gap that needs to address related to this issue. To solve the model, this paper develops two methods, namely method of optimal and method of heuristic. The method of heuristic is developed based on algorithm of simulated annealing and is applied in city of Jakarta to design a new supply chain for food and improve the effectiveness and efficiency.

In the last 10 years, here are papers related to LIRP model. Sajjadi and Cheraghi (2011) developed LIRP model and solved it using simulated annealing. The model consisted of probabilistic demands, multi products, and multi echelons. Depots and customers were the places where decisions of inventory made. Guerrero, Prodhon, Velasco and Amaya (2013) developed LIRP model and solved it using local search and algorithm of randomized extended Clarke and Wright. The model consisted of deterministic demand, single product, and single echelon. In Guerrero et al. (2013), depots and customers were the places where decisions of inventory made. Nekooghadirli, Tavakkoli-Moghaddam, Ghezavati and Javanmard (2014) developed LIRP model and solved it using algorithm of multi-objective meta-heuristic. The model consisted of probabilistic demands, multi products, and multi echelons. Distribution centers were the places where decisions of inventory made. Zhang, Qi, Miao and Liu (2014) developed LIRP model where customers were the places where decisions of inventory made. Zhang et al. (2014) solved the model using simulated annealing and local search. The model consisted of deterministic demand, single product, and multi echelons.

Tang, Ji and Jiang (2016) developed LIRP model and solved it using multi-objective particle swarm optimization. Warehouses were the places where decisions of inventory made. The model in Tang et al. (2016) consisted of probabilistic demand, single product, and multi echelons. Ghorbani \& Akbari-Jokar (2016) developed LIRP model and solved it using imperialist competitive and simulated annealing. The model consisted of probabilistic demands, multi products, and multi echelons. Depots and customers were the places where decisions of inventory made. Zhalechian, Tavakkoli-Moghaddam, Zahiri and Mohammadi (2016) developed LIRP model and solved it using variable neighborhood search and self-adaptive genetic algorithm. The model consisted of probabilistic demands, multi products, and multi echelons. Distribution centers were the places where decisions of inventory made. Hiassat, Diabat and Rahwan (2017) developed LIRP model that consisted of deterministic demands, single product, and single echelon. The model solved using genetic algorithm. Customers were the places where decisions of inventory made. Rayat, Musavi and Bozorgi-Amiri (2017) developed LIRP model and solved it using archived multi-objective simulated annealing. Distribution centers were the places where decisions of inventory made. The model consisted of deterministic demands, multi products, and multi echelons.

Rafie-Majd, Pasandideh and Naderi (2018) developed LIRP model that consisted of deterministic demands, multi products, and multi echelons. The model was solved using algorithm of Lagrangian relaxation. Customers were the places where decisions of inventory made. Vahdani, Veysmoradi, Noori and Mansour (2018) developed LIRP model and solved it using multi-objective particle swarm optimization and non-dominated sorting genetic algorithm II. The model consisted of probabilistic demands, multi products, and multi echelons. Distribution centers/warehouses were the places where decisions of inventory made. Saragih, Bahagia, Suprayogi and Syabri (2019) developed LIRP model and solved it using simulated annealing. The model consisted of probabilistic demand, single product, and multi echelons. Retailers, depots and supplier were the places where decisions of inventory made. Bagherinejad \& Najafi-Ghobadi (2019) developed LIRP model and solved it using genetic algorithm and algorithm of evolutionary simulated annealing. The model consisted of deterministic demand, single product, and multi echelons. Retailers and warehouses were the places where decisions of inventory made.

Farias, Hadj-Hamou and Yugma (2020) developed LIRP model and solved it using algorithm of Branch-and-Cut and two-phase heuristic. The model consisted of deterministic demand, single product, and multi echelons. Customers, distribution centers, and supplier were the places where decisions of inventory made. Rahbari, 
Razavi-Hajiagha, Raeei-Dehaghi, Moallem and Riahi-Dorcheh (2020) developed LIRP model that consisted of deterministic demand, single product, and multi echelons. The model was solved using general algebraic modeling system. Decisions of inventory made at all entities. Karakostas, Sifaleras and Georgiadis (2020) developed LIRP model and solved it using general variable neighbourhood search. The model consisted of deterministic demand, single product, and single echelon.

\begin{tabular}{|c|c|c|c|c|c|c|c|c|c|c|}
\hline \multirow[b]{2}{*}{ Papers } & \multicolumn{2}{|c|}{\begin{tabular}{|l|} 
Number \\
of products
\end{tabular}} & \multicolumn{3}{|c|}{ Decisions of inventory } & \multicolumn{2}{|c|}{\begin{tabular}{|l|} 
Number \\
of echelons
\end{tabular}} & \multicolumn{2}{|c|}{$\begin{array}{l}\text { Number } \\
\text { of links }\end{array}$} & \multirow[b]{2}{*}{ Heuristic methods } \\
\hline & Single & Multi & $\begin{array}{l}\text { Customers/ } \\
\text { Retailers }\end{array}$ & $\begin{array}{c}\text { Depots/ } \\
\text { Distribution centers/ } \\
\text { Warehouses }\end{array}$ & $\begin{array}{l}\text { Suppliers/ } \\
\text { Plants }\end{array}$ & Single & Multi & Single & Multi & \\
\hline $\begin{array}{l}\text { Sajjadi \& } \\
\text { Cheraghi (2011) }\end{array}$ & & $\sqrt{ }$ & $\sqrt{ }$ & $\sqrt{ }$ & & & $\sqrt{ }$ & $\sqrt{ }$ & & Simulated annealing \\
\hline $\begin{array}{l}\text { Guerrero et al. } \\
\text { (2013) }\end{array}$ & $\sqrt{ }$ & & $\sqrt{ }$ & $\sqrt{ }$ & & $\sqrt{ }$ & & $\sqrt{ }$ & & $\begin{array}{l}\text { Local search and } \\
\text { algorithm of } \\
\text { randomized extended } \\
\text { Clarke and Wright }\end{array}$ \\
\hline $\begin{array}{l}\text { Nekooghadirli } \\
\text { et al. (2014) }\end{array}$ & & $\sqrt{ }$ & & $\sqrt{ }$ & & & $\sqrt{ }$ & $\sqrt{ }$ & & $\begin{array}{l}\text { Algorithm of multi- } \\
\text { objective meta- } \\
\text { heuristic }\end{array}$ \\
\hline $\begin{array}{l}\text { Zhang et al. } \\
\text { (2014) }\end{array}$ & $\sqrt{ }$ & & $\sqrt{ }$ & & & & $\sqrt{ }$ & $\sqrt{ }$ & & $\begin{array}{l}\text { Simulated annealing } \\
\text { and local search }\end{array}$ \\
\hline $\begin{array}{l}\text { Tang et al. } \\
\text { (2016) }\end{array}$ & $\sqrt{ }$ & & & $\sqrt{ }$ & & & $\sqrt{ }$ & $\sqrt{ }$ & & $\begin{array}{l}\text { Multi-objective } \\
\text { particle swarm } \\
\text { optimization }\end{array}$ \\
\hline $\begin{array}{l}\text { Ghorbani \& } \\
\text { Akbari-Jokar } \\
\text { (2016) }\end{array}$ & & $\sqrt{ }$ & $\sqrt{ }$ & $\sqrt{ }$ & & & $\sqrt{ }$ & $\sqrt{ }$ & & $\begin{array}{l}\text { Imperialist } \\
\text { competitive and } \\
\text { simulated annealing }\end{array}$ \\
\hline $\begin{array}{l}\text { Zhalechian et al. } \\
\text { (2016) }\end{array}$ & & $\sqrt{ }$ & & $\sqrt{ }$ & & & $\sqrt{ }$ & $\sqrt{ }$ & & $\begin{array}{l}\text { Variable } \\
\text { neighbourhood } \\
\text { search and self- } \\
\text { adaptive genetic } \\
\text { algorithm }\end{array}$ \\
\hline $\begin{array}{l}\text { Hiassat et al. } \\
\text { (2017) }\end{array}$ & $\sqrt{ }$ & & $\sqrt{ }$ & & & $\sqrt{ }$ & & $\sqrt{ }$ & & Genetic algorithm \\
\hline $\begin{array}{l}\text { Rayat et al. } \\
\text { (2017) }\end{array}$ & & $\sqrt{ }$ & & $\sqrt{ }$ & & & $\sqrt{ }$ & $\sqrt{ }$ & & $\begin{array}{l}\text { Archived multi- } \\
\text { objective simulated } \\
\text { annealing }\end{array}$ \\
\hline $\begin{array}{l}\text { Rafie-Majd et al. } \\
\text { (2018) }\end{array}$ & & $\sqrt{ }$ & $\sqrt{ }$ & & & & $\sqrt{ }$ & $\sqrt{ }$ & & $\begin{array}{l}\text { Algorithm of } \\
\text { Lagrangian relaxation }\end{array}$ \\
\hline $\begin{array}{l}\text { Vahdani et al. } \\
\text { (2018) }\end{array}$ & & $\sqrt{ }$ & & $\sqrt{ }$ & & $\sqrt{ }$ & & $\sqrt{ }$ & & $\begin{array}{l}\text { Multi-objective } \\
\text { particle swarm } \\
\text { optimization and } \\
\text { non-dominated } \\
\text { sorting genetic } \\
\text { algorithm II }\end{array}$ \\
\hline $\begin{array}{l}\text { Saragih et al. } \\
\text { (2019) }\end{array}$ & $\sqrt{ }$ & & $\sqrt{ }$ & $\sqrt{ }$ & $\sqrt{ }$ & & $\sqrt{ }$ & $\sqrt{ }$ & & Simulated annealing \\
\hline $\begin{array}{l}\text { Bagherinejad \& } \\
\text { Najafi-Ghobadi } \\
\text { (2019) }\end{array}$ & $\sqrt{ }$ & & $\sqrt{ }$ & $\sqrt{ }$ & & $\sqrt{ }$ & & $\sqrt{ }$ & & $\begin{array}{l}\text { Genetic algorithm } \\
\text { and algorithm of } \\
\text { evolutionary } \\
\text { simulated annealing }\end{array}$ \\
\hline
\end{tabular}




\begin{tabular}{|c|c|c|c|c|c|c|c|c|c|c|}
\hline \multirow[b]{2}{*}{ Papers } & \multicolumn{2}{|c|}{$\begin{array}{l}\text { Number } \\
\text { of products }\end{array}$} & \multicolumn{3}{|c|}{ Decisions of inventory } & \multicolumn{2}{|c|}{$\begin{array}{l}\text { Number } \\
\text { of echelons }\end{array}$} & \multicolumn{2}{|c|}{$\begin{array}{l}\text { Number } \\
\text { of links }\end{array}$} & \multirow[b]{2}{*}{ Heuristic methods } \\
\hline & Single & Multi & $\begin{array}{l}\text { Customers/ } \\
\text { Retailers }\end{array}$ & $\begin{array}{c}\text { Depots/ } \\
\text { Distribution centers/ } \\
\text { Warehouses }\end{array}$ & $\mid \begin{array}{c}\text { Suppliers/ } \\
\text { Plants }\end{array}$ & Single & Multi & Single & Multi & \\
\hline $\begin{array}{l}\text { Farias et al. } \\
(2020)\end{array}$ & $\sqrt{ }$ & & $\sqrt{ }$ & $\sqrt{ }$ & $\sqrt{ }$ & & $\sqrt{ }$ & $\sqrt{ }$ & & $\begin{array}{l}\text { Branch-and-Cut and } \\
\text { two-phase heuristic }\end{array}$ \\
\hline $\begin{array}{l}\text { Rahbari et al. } \\
(2020)\end{array}$ & $\sqrt{ }$ & & $\sqrt{ }$ & $\sqrt{ }$ & $\sqrt{ }$ & & $\sqrt{ }$ & $\sqrt{ }$ & & $\begin{array}{l}\text { General algebraic } \\
\text { modeling system }\end{array}$ \\
\hline $\begin{array}{l}\text { Karakostas et al. } \\
(2020)\end{array}$ & $\sqrt{ }$ & & $\sqrt{ }$ & & & $\sqrt{ }$ & & $\sqrt{ }$ & & $\begin{array}{l}\text { General variable } \\
\text { neighborhood search }\end{array}$ \\
\hline This paper & & $\sqrt{ }$ & $\sqrt{ }$ & $\sqrt{ }$ & $\sqrt{ }$ & & $\sqrt{ }$ & & $\sqrt{ }$ & Simulated annealing \\
\hline
\end{tabular}

Table 1. Papers in LIRP model

The LIRP model developed in this paper consists of probabilistic demands, multi products, and multi echelons. Traditional markets, UCCs (urban consolidation centers) and province of suppliers are the places where decisions of inventory made. UCCs are logistics facilities where consolidation and coordination activities are performed (Saragih et al., 2015). As for the main contribution, this paper considers multiple links to represent the road networks in urban areas, such as the city of Jakarta. The model developed in this paper represents more realistic real systems where there are multiple road networks that connect places in urban areas. From Table 1, this model of LIRP has never been done before. This paper fills the gap by developing the LIRP model.

\section{Methodology}

To develop the LIRP model, this paper uses Saragih et al. (2018) and Taniguchi, Noritake, Yamada and Izumitani (1999) as the refences. Saragih et al. (2018) only considered one link or road to connect two locations in the LIRP model, whereas in urban areas, two locations can be connected by more than one link. This weakness is improved using Taniguchi et al. (1999). The approach used to develop the LIRP model in this paper can be seen in Figure 1.

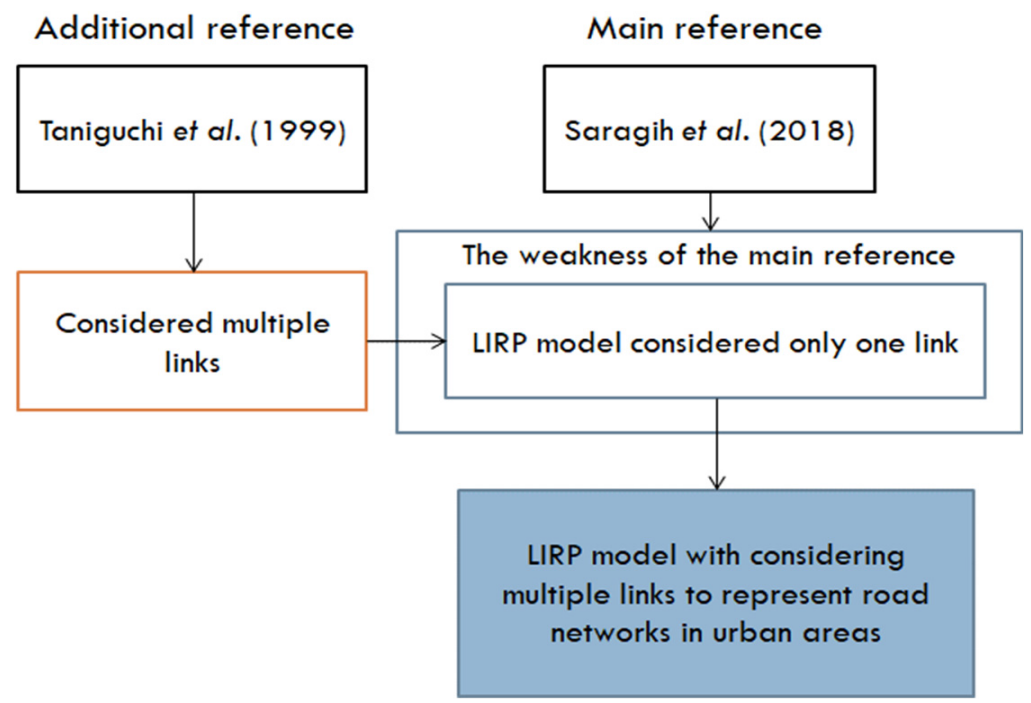

Figure 1. The approach for the development of the model

The illustration of system studied can be seen in Figure 2. Figure 2 consists of two province of suppliers, two UCCS, four traditional markets (TMs), and two links. Link 1 is the green line and link 2 is the blue line. 


\section{Province of supplier 1}

\section{Province of supplier 2}

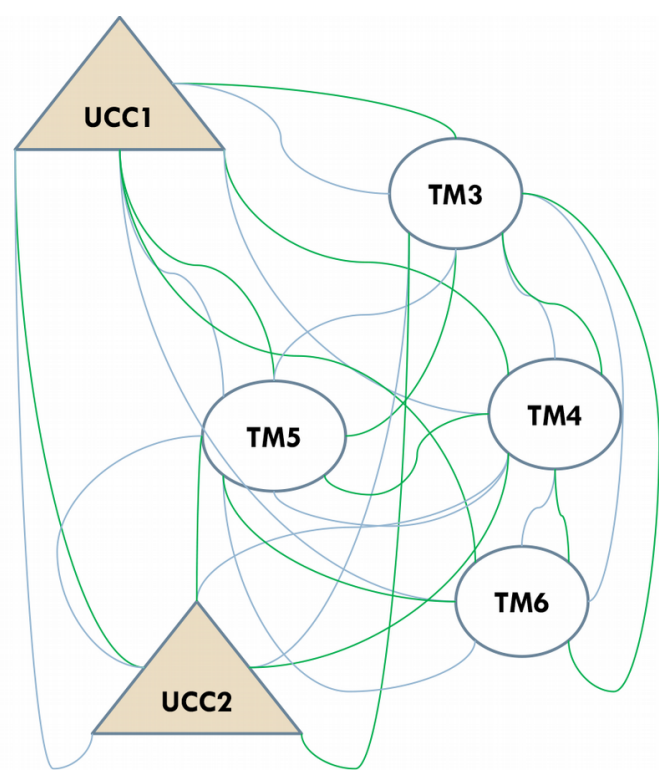

Figure 2. The illustration of system studied

\section{Development of Model}

The LIRP model developed in this paper is described as follows.

\begin{tabular}{|l|l|}
\hline \multicolumn{2}{|l|}{ Index sets } \\
\hline$K$ & set of traditional markets \\
\hline$J$ & set of potential UCCs \\
\hline$N_{j}$ & set of capacity levels available to UCC $(j \in J)$ \\
\hline$I$ & set of province of suppliers \\
\hline$P$ & set of products \\
\hline$V$ & set of vehicles \\
\hline$M$ & merged set of traditional markets and potential UCCs, i.e. $(K \cup J)$ \\
\hline$O_{k l}$ & set of links between node $k$ and node $(k, l \in M)$ \\
\hline
\end{tabular}

\begin{tabular}{|l|l|}
\hline \multicolumn{2}{|l|}{ Index } \\
\hline$k$ & index of traditional markets \\
\hline$j$ & index of UCCs \\
\hline$n$ & index of capacity levels available to UCC \\
\hline$i$ & index of province of suppliers \\
\hline$p$ & index of products \\
\hline$v$ & index of vehicles \\
\hline$o$ & index of links \\
\hline
\end{tabular}




\begin{tabular}{|c|c|}
\hline \multicolumn{2}{|c|}{ Parameters and notations } \\
\hline$\mu_{k p}$ & mean of demand at traditional market $k$ for product $p(\mathrm{~kg} /$ day $)(\forall k \in K, \forall p \in P)$ \\
\hline$\sigma_{k p}^{2}$ & variance of demand at traditional market $k$ for product $p\left(\mathrm{~kg}^{2} / \mathrm{day}^{2}\right)(\forall k \in K, \forall p \in P)$ \\
\hline$b_{k p}$ & inventory holding cost at traditional market $k$ for product $p(\mathrm{Rp} / \mathrm{kg} /$ day $)(\forall k \in K, \forall p \in P)$ \\
\hline$a_{k p}$ & ordering cost at traditional market $k$ for product $p(\mathrm{Rp} /$ order $)(\forall k \in K, \forall p \in P)$ \\
\hline$l t_{k p}$ & lead time of traditional market $k$ for product $p$ (day) $(\forall k \in K, \forall p \in P$ ) \\
\hline$s_{k p}$ & shortage cost at traditional market $k$ for product $p(\mathrm{Rp} / \mathrm{kg})(\forall k \in K, \forall p \in P)$ \\
\hline$\alpha$ & service level for traditional market \\
\hline$z_{\alpha}$ & standard normal deviate such that $P\left(Z \leq z_{\alpha}\right)=\alpha$ \\
\hline$f(z \alpha)$ & ordinate of $q_{\alpha}$ \\
\hline$\psi(z \alpha)$ & partial expectations of $z \alpha$ \\
\hline$f_{j}^{n}$ & fixed cost for opening and operating UCC $j$ with capacity level $n(\mathrm{Rp} /$ day $)\left(\forall j \in J, \forall n \in N_{j}\right)$ \\
\hline$b_{j}^{n}$ & capacity with level $n$ for UCC $j(\mathrm{~kg} /$ day $)\left(\forall j \in J, \forall n \in N_{j}\right)$ \\
\hline$d_{k l}$ & distance between node $k$ and node $l(\mathrm{~km})$ \\
\hline$t_{k l}$ & time loss between node $k$ and node $l$ (hour) \\
\hline$c a$ & transportation cost $(\mathrm{Rp} / \mathrm{km})$ \\
\hline$c b$ & value of time (Rp/hour) \\
\hline$b_{j p}$ & inventory holding cost at UCC $j$ for product $p(\mathrm{Rp} / \mathrm{kg} / \mathrm{day})(\forall j \in J, \forall p \in P)$ \\
\hline$a_{j p}$ & ordering cost at UCC $j$ for product $p(\mathrm{Rp} /$ order $)(\forall j \in J, \forall p \in P)$ \\
\hline$l t_{j p}$ & lead time of $\mathrm{UCC} j$ for product $p$ (day) $(\forall j \in J, \forall p \in P$ ) \\
\hline$v c$ & capacity of vehicle (kg) \\
\hline$b_{i p}$ & inventory holding cost at province of supplier $i$ for product $p(\mathrm{Rp} / \mathrm{kg} /$ day $)(\forall i \in I, \forall p \in P)$ \\
\hline$a_{\text {ip }}$ & ordering cost at province of supplier $i$ for product $p(\mathrm{Rp} /$ order $)(\forall i \in I, \forall p \in P)$ \\
\hline$l t_{i p}$ & lead time of province of supplier $i$ for product $p$ (day) $(\forall i \in I, \forall p \in P)$ \\
\hline$b_{\text {ip }}$ & capacity for province of supplier $i$ for product $p$ (kg/day) $(\forall i \in I, \forall p \in P)$ \\
\hline$w$ & transportation cost of truck (Rp/truck) \\
\hline$p p$ & capacity of truck $(\mathrm{kg})$ \\
\hline$B$ & number of customers contained in set $K$, i.e., $B=|K|$ \\
\hline TC & total cost (Rp/day) \\
\hline$T$ & single cycle time (day) \\
\hline
\end{tabular}

\begin{tabular}{|l|l|}
\hline \multicolumn{2}{|l|}{ Decision variables } \\
\hline$N P_{k p}$ & order frequency of traditional market $k$ for product $p(\forall k \in K, \forall p \in P)$ \\
\hline$E$ & order frequency of every traditional market and product \\
\hline$Q_{k p}$ & lot size of traditional market $k$ for product $p(\mathrm{~kg})(\forall k \in K, \forall p \in P)$ \\
\hline$Q_{k}$ & total lot size of traditional market $k(\mathrm{~kg})$ \\
\hline$M K_{k p}$ & number of shortage at traditional market $k$ for product $p$ (Unit) $(\forall k \in K, \forall p \in P)$ \\
\hline
\end{tabular}




\begin{tabular}{|c|c|}
\hline$R K_{k p}$ & reorder point at traditional market $k$ for product $p$ (Unit) $(\forall k \in K, \forall p \in P$ ) \\
\hline$S S_{k p}$ & safety stock at traditional market $k$ for product $p$ (Unit) $(\forall k \in K, \forall p \in P)$ \\
\hline$M_{k v}$ & auxiliary variable defined for traditional market $k$ for subtour elimination in route of vehicle $v(\forall k \in K, \forall v \in V)$ \\
\hline$U_{j}^{n}$ & $\begin{array}{c}1 \text { if UCC } j \text { is opened with capacity level } n \\
0 \text { otherwise }\end{array} \quad\left(\forall j \in J, \forall n \in N_{j}\right)$ \\
\hline$Y_{j k}$ & $\left\{\begin{array}{c}1 \text { if traditional market } k \text { is assigned to UCC } j \\
0 \text { otherwise }\end{array} \quad(\forall j \in J, \forall k \in K)\right.$ \\
\hline $\mathrm{R}_{k l w}^{o}$ & $\left\{\begin{array}{c}1 \text { if } k \text { precedes } l \text { in route of vehicle } v \text { on link } o \\
0 \text { otherwise }\end{array} \quad\left(\forall k, l \in M, \forall v \in V, o \in O_{k l}\right)\right.$ \\
\hline$D_{j p}$ & demand of UCC $j$ for product $p$ (kg/day) $(\forall j \in J, \forall p \in P)$ \\
\hline$N P_{j p}$ & order frequency of UCC $j$ for product $p(\forall j \in J, \forall p \in P)$ \\
\hline$Z$ & order frequency of every UCC and product \\
\hline$Q_{i p}$ & lot size of UCC $j$ for product $p(\mathrm{~kg})(\forall j \in J, \forall p \in P)$ \\
\hline$Q_{j}$ & total lot size of UCC $j(\mathrm{~kg})$ \\
\hline$R K_{j p}$ & reorder point at UCC $j$ for product $p(\mathrm{~kg})(\forall j \in J, \forall p \in P)$ \\
\hline$X_{j}$ & number of truck at UCC $j$ (Truck) $(\forall j \in J)$ \\
\hline$G_{\ddot{p} p}$ & $\left\{\begin{array}{cc}1 \text { if province of supplier } i \text { supplies UCC } j \text { for product } p & \\
0 \text { otherwise } & (\forall i \in I, \forall j \in J, \forall p \in P)\end{array}\right.$ \\
\hline$D_{i p}$ & demand of province of supplier $i$ for product $p$ (kg/day) $(\forall j \in J, \forall p \in P$ ) \\
\hline$Q_{i p}$ & lot size of province of supplier $i$ for product $p(\mathrm{~kg})(\forall j \in J, \forall p \in P)$ \\
\hline$Q_{i}$ & total lot size of province of supplier $i(\mathrm{~kg})(\forall i \in I)$ \\
\hline$R K_{i p}$ & reorder point at province of supplier $i$ for product $p(\mathrm{~kg})(\forall j \in J, \forall p \in P)$ \\
\hline$X_{i}$ & number of truck at province of supplier $i$ (truck) $(\forall i \in I)$ \\
\hline$V_{i j p}$ & amount of demand of UCC $i$ for product $p$ supplied by province of supplier $i(\forall i \in I, \forall j \in J, \forall p \in P$ ) \\
\hline
\end{tabular}

\subsection{The LIRP Model}

The costs consist of:

1. The fixed cost of locating the opened UCCs, given as $\sum_{j \in J} \sum_{n \in N_{j}} f_{j}^{n} U_{j}^{n}$

2. The routing cost from the opened UCCs to the traditional markets, given as $\frac{E}{T} \sum_{v \in V} \sum_{o \in O_{k l}} \sum_{k \in M} \sum_{l \in M}\left(d_{k l}^{o} c a+t_{k l}^{o} c b\right) R_{k l v}^{o}$

3. The expected inventory cost in traditional markets, given as

$$
\sum_{k \in K} \sum_{p \in P}\left[\frac{a_{k p} \mu_{k p}}{Q_{k p}}+h_{k p}\left(\frac{Q_{k p}}{2}+S S_{k p}\right)+s_{k p} M K_{k p}\left(\frac{\mu_{k p}}{Q_{k p}}\right)\right]
$$

4. The expected inventory cost in UCCs, given as

$$
\sum_{j \in J} \sum_{p \in P}\left[\frac{a_{j p} D_{j p}}{Q_{j p}}+h_{j p}\left(\frac{Q_{j p}}{2}+\sum_{k}\left(l t_{k p} \mu_{k p}+S S_{k p}\right) Y_{j k}\right)+w X_{j} \frac{Z}{T}\right]
$$


5. The expected inventory cost in province of suppliers, given as

$$
\sum_{i \in I} \sum_{p \in P}\left[\frac{a_{i p} D_{i p}}{Q_{i p}} h_{i p}\left(\frac{Q_{i p}}{2}+\left(\sum_{j} \sum_{k}\left(\left(l t_{j p}+l t_{k p}\right) \mu_{k p}+S S_{k p}\right) Y_{j k}\right) G_{i j p}\right)+w X_{i} \frac{1}{T}\right]
$$

Objective function:

$$
\begin{aligned}
& \min T C=\sum_{j \in J} \sum_{n \in N_{j}} f_{j}^{n} U_{j}^{n}+\frac{E}{T} \sum_{v \in V} \sum_{o \in O_{k l}} \sum_{k \in M} \sum_{l \in M}\left(d_{k l}^{o} c a+t_{k l}^{o} c b\right) R_{k l v}^{o}+ \\
& \sum_{k \in K} \sum_{p \in P}\left[\frac{a_{k p} \mu_{k p}}{Q_{k p}}+h_{k p}\left(\frac{Q_{k p}}{2}+S S_{k p}\right)+s_{k p} M K_{k p}\left(\frac{\mu_{k p}}{Q_{k p}}\right)\right]+\sum_{j \in J} \sum_{p \in P}\left[\frac{a_{j p} D_{j p}}{Q_{j p}}+h_{j p}\left(\frac{Q_{j p}}{2}+\right.\right. \\
& \left.\left.\sum_{k}\left(l t_{k p} \mu_{k p}+S S_{k p}\right) Y_{j k}\right)+w X_{j} \frac{Z}{T}\right]+\sum_{i \in I} \sum_{p \in P}\left[\frac{a_{i p} D_{i p}}{Q_{i p}}+h_{i p}\left(\frac{Q_{i p}}{2}+\left(\sum _ { j } \sum _ { k } \left(\left(l t_{j p}+\right.\right.\right.\right.\right. \\
& \left.\left.\left.\left.\left.l t_{k p}\right) \mu_{k p}+S S_{k p}\right) Y_{j k}\right) G_{i j p}\right)+w X_{i} \frac{1}{T}\right]
\end{aligned}
$$

Subject to:

$$
\begin{gathered}
\sum_{v \in V} \sum_{o \in O_{k l}} \sum_{l \in M} R_{k l v}^{o}=1, \forall k \in K \\
\sum_{o \in O_{k l}} \sum_{l \in K} \sum_{k \in M} Q_{l} R_{k l v}^{o} \leq v c, \forall v \in V \\
M_{k v}-M_{l v}+\left(B \times R_{k l v}^{o}\right) \leq B-1, \forall k, l \in K, \forall o \in O_{k l}, \forall v \in V \\
\sum_{o \in O_{k l}} \sum_{l \in M} R_{k l v}^{o}-\sum_{o \in O_{k l}} \sum_{l \in M} R_{k l v}^{o}=0, \forall k \in M, \forall v \in V \\
\sum_{o \in O_{k l}} \sum_{j \in J} \sum_{k \in K} R_{k l v}^{o} \leq 1, \forall v \in V \\
\sum_{o \in O_{k l}} \sum_{l \in M} R_{k l v}^{o}+\sum_{o \in O_{k l}} \sum_{l \in M} R_{k l v}^{o}-Y_{j k} \leq 1, \forall j \in j, \forall k \in K, \forall v \in V \\
\sum_{o \in O_{k l}} R_{k l v}^{o} \leq 1, \forall v \in V, \forall k, l \in M \\
\sum_{n \in N_{j}} U_{j}^{n} \leq 1, \forall j \in J \\
\sum_{k \in K} \sum_{p \in P} \mu_{k p} Y_{j k} \leq \sum_{n \in N_{j}} b_{j}^{n} U_{j}^{n}, \forall j \in J \\
\sum_{k \in K} \mu_{k p} Y_{j k}=\sum_{n \in N_{j}} D_{j p} U_{j}^{n}, \forall p \in P, \forall j \in J \\
\sum_{j \in J} Y_{j k}=1, \forall k \in K \\
\sum_{n \in N_{j}} D_{j p} U_{j}^{n}=\sum_{i j p} \geq 1, \forall p \in P, \forall i \in I \\
\sum_{j \in J} V_{i j p}=D_{i p}, \forall p \in P, \forall i \in I \\
\sum_{j \in J} V_{i j p} \leq b_{i p}, \forall i \in I \\
S_{k p}=z_{\alpha} \sqrt{l i j p}_{k p} \sigma_{k p}^{2}, \forall p \in P, \forall j \in J
\end{gathered}
$$




$$
\begin{aligned}
& M K_{k p}=\sqrt{l t_{k p} \sigma_{k p}^{2}}\left[f\left(z_{\alpha}\right)-z_{\alpha} \psi\left(z_{\alpha}\right)\right], \forall p \in P, \forall k \in K \\
& R K_{k p}=l t_{k p} \mu_{k p}+S S_{k p}, \forall p \in P, \forall k \in K \\
& R K_{j p}=\left(\sum_{k}\left(l t_{j p}+l t_{k p}\right) \mu_{k p}+S S_{k p}\right) Y_{j k}, \forall p \in P, \forall j \in J \\
& R K_{i p}=\left(\sum_{k} l t_{i p} \mu_{k p}+\left(\sum_{j} \sum_{k}\left(l t_{j p}+l t_{k p}\right) \mu_{k p}+S S_{k p}\right) Y_{j k}\right) G i j p, \forall p \in P, \forall i \in I \\
& T=\frac{Q_{i p}}{D_{i p}}=\frac{N P_{j p} Q_{j p}}{D_{j p}}=\frac{N P_{j p} N P_{k p} Q_{k p}}{\mu_{k p}}, \forall p \in P, \forall k \in K, \forall j \in J \\
& N P_{k p}=E, \forall p \in P, \forall k \in K \\
& N P_{j p}=Z, \forall p \in P, \forall j \in J \\
& \sum_{p \in P} Q_{k p}=Q_{k}, \forall k \in K \\
& \sum_{p \in P} Q_{j p}=Q_{j}, \forall j \in J \\
& \sum_{p \in P} Q_{i p}=Q_{i}, \forall i \in I \\
& X_{j}=\left\lceil\frac{Q_{j}}{p p}\right\rceil, \forall j \in J \\
& X_{i}=\left\lceil\frac{Q_{i}}{p p}\right\rceil, \forall i \in I \\
& U_{j}^{n} \in\{0,1\}, \forall j \in J, \forall n \in N_{j} \\
& Y_{j k} \in\{0,1\}, \forall j \in J, \forall k \in J \\
& R_{k l v}^{o} \in\{0,1\}, \forall k, l \in M, \forall o \in O_{k l}, \forall v \in V \\
& G_{i j p} \in\{0,1\}, \forall p \in P, \forall j \in J, \forall i \in I \\
& M_{k v} \geq 0, \forall k \in K, \forall v \in V \\
& Q_{i p}, Q_{j p}, Q_{k p} \geq 0, \forall p \in P, \forall i \in I, \forall j \in J, \forall k \in K \\
& T \geq 0 \\
& E, Z, N P_{j p}, N P_{k p} \geq 1, E, Z, N P_{j p}, N P_{k p} \in i n t, \forall j \in J, \forall k \in K, \forall p \in P \\
& V_{i j p} \geq 0, \forall p \in P, \forall j \in J, \forall i \in I
\end{aligned}
$$

Equation (1) is the total cost. Constraints (2) guarantee that each traditional market is served exactly once by a vehicle. Constraints (3) ensure that products sent in one vehicle route may not exceed the vehicle's capacity. Constraints (4) are the subtour elimination. Constraints (5) are the flow conservation. Constraints (6) guarantee that 
only one UCC per route. Constraints (7) connect allocation and routing decisions. Constraints (8) guarantee that each vehicle can only traverse one link. Constraints (9) guarantee that each UCC can only have one level capacity. Constraints (10) guarantee that a UCC must not supply traditional markets beyond its capacity. Constraints (11) guarantee that demands in a UCC for each product is the sum of the demands for the traditional markets served for each product. Constraints (12) guarantee that each traditional market is supplied exactly once by a UCC. Constraints (13) guarantee each province of supplier can service more than one UCC and one product. Constraints (14) guarantee that demands at province of supplier are the demands for each product that can be supplied to UCC without exceeding its capacity. Constraints (15) guarantee that demands of each UCC for each product must be fulfilled by province of supplier. Constraints (16) guarantee that demands at province of suppliers are the demands for each product supplied to UCC served. Constraints (22) are single cycle time. Constraints (23) are frequency of order for traditional markets. Constraints (24) are frequency of order for UCCs. Constraints (25) are lot size of all products in traditional market. Constraints (26) are lot size of all products in UCC. Constraints (27) are lot size of all products in province of supplier. Constraints (30)-(38) are the constraints for decision variables.

The LIRP model developed in this paper is MINLP (mixed integer nonlinear programming) model. Since LIRP belongs to the class of NP-hard problems, the application of the MINLP model is limited to small data (Ahmadi-Javid \& Azad, 2010). To apply the model in a real system case which is Jakarta, it needs method of heuristic. The method of heuristic based on algorithm of SA (simulated annealing) is developed in this paper. SA is algorithm of local search (meta-heuristic) that is capable of escaping from local optima. It is used to solve discrete and to a lesser extent, continuous optimization problems (Henderson, Jacobson \& Johnson, 2003). The LIRP consists of location and routing problems which are discrete optimization problems and inventory problem which is continuous optimization problems. SA is appropriate to solve the model in this paper.

\section{Solution Method}

As it was mentioned previously, to solve the LIRP model, this paper develops method of heuristic based on algorithm of SA. Solution resulted from the method of heuristic is compared to the solution resulted from method of optimal (the MINLP). The method of heuristic uses parameters as follows.

\begin{tabular}{|l|l|}
\hline \multicolumn{2}{|l|}{ Parameters of the method of heuristic } \\
\hline$I_{0}$ & initial temperature \\
\hline$I_{a}$ & final temperature \\
\hline$I_{c}$ & current temperature \\
\hline$\beta_{0}$ & initial solution \\
\hline$\beta_{a}$ & final solution \\
\hline$\beta_{c}$ & current solution \\
\hline$\theta$ & cooling rate \\
\hline$C_{m a x}$ & iteration maximum number at every level of temperature \\
\hline$\Delta$ & TC $\left(\beta_{c}\right)-$ TC $\left(\beta_{a}\right)$ \\
\hline$r$ & random number between 0 and 1 \\
\hline$T C\left(\beta_{0}\right)$ & value of objective function for initial solution \\
\hline$T C\left(\beta_{a}\right)$ & value of objective function for final solution \\
\hline$T C\left(\beta_{c}\right)$ & value of objective function for current solution \\
\hline
\end{tabular}

Pseudo code of the method of heuristic is given in Figure 3. 


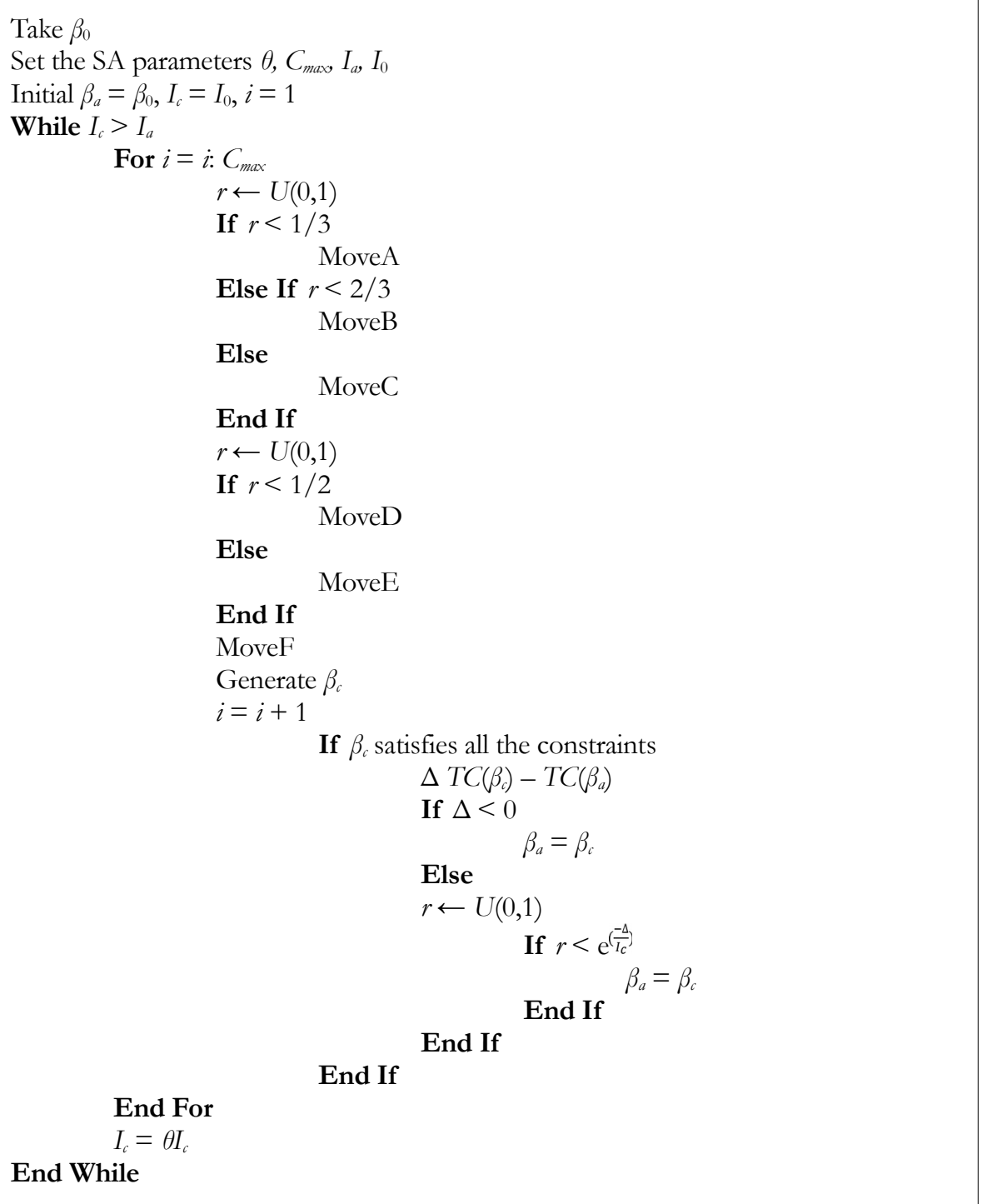

Figure 3. Pseudo code of the method of heuristic

All moves used in this paper are adopted from Saragih et al. (2019).

\section{Computational Experiments}

Example of solution for the LIRP model is given in Figure 4. The solution is resulted from method of optimal by running the model in LINGO 12.0. Data used for the problem in Figure 4 are described as follows.

\begin{tabular}{|c|c|c|c|c|c|c|c|c|c|c|c|c|}
\hline \multirow{2}{*}{$\begin{array}{c}\text { Traditional } \\
\text { market/product }\end{array}$} & \multicolumn{2}{|c|}{$\begin{array}{c}\mu_{k p} \\
(\mathrm{~kg} / \mathrm{day})\end{array}$} & \multicolumn{2}{|c|}{$\begin{array}{c}\sigma^{2} k p \\
(\mathrm{~kg} / \text { day })\end{array}$} & \multicolumn{2}{|c|}{$\begin{array}{c}a_{k p} \\
(\mathrm{Rp} / \text { order })\end{array}$} & \multicolumn{2}{|c|}{$\begin{array}{c}h_{k p} \\
(\mathrm{Rp} / \mathrm{kg} / \text { period) }\end{array}$} & \multicolumn{2}{|c|}{$\begin{array}{c}b_{k p} \\
(\mathrm{Rp} / \mathrm{kg})\end{array}$} & \multicolumn{2}{|c|}{$\begin{array}{l}1 t_{k p} \\
\text { (day) }\end{array}$} \\
\hline & 1 & 2 & 1 & 2 & 1 & 2 & 1 & 2 & 1 & 2 & 1 & 2 \\
\hline 3 & 10 & 15 & 2 & 2 & 4 & 4 & 2 & 2 & 1 & 1 & 0.25 & 0.25 \\
\hline 4 & 20 & 25 & 3 & 3 & 4 & 4 & 2 & 2 & 1 & 1 & 0.25 & 0.25 \\
\hline 5 & 30 & 35 & 4 & 4 & 4 & 4 & 2 & 2 & 1 & 1 & 0.25 & 0.25 \\
\hline 6 & 40 & 45 & 5 & 5 & 4 & 4 & 2 & 2 & 1 & 1 & 0.25 & 0.25 \\
\hline
\end{tabular}

Table 2. Data used in traditional market $k$ 


\begin{tabular}{|c|c|c|c|c|c|c|c|c|c|c|c|}
\hline \multirow[b]{2}{*}{ UCC/product } & \multicolumn{2}{|c|}{$\begin{array}{c}b_{j}^{n} \\
(\mathrm{~kg} / \mathrm{day})\end{array}$} & \multicolumn{2}{|c|}{$\begin{array}{c}f_{j}^{n} \\
(\mathrm{Rp} / \mathrm{day})\end{array}$} & \multicolumn{2}{|c|}{$\begin{array}{c}a_{j p} \\
(\mathbf{R p} / \text { order) }\end{array}$} & \multicolumn{2}{|c|}{$\begin{array}{c}\boldsymbol{h}_{j p} \\
(\mathrm{Rp} / \mathrm{kg} / \text { period })\end{array}$} & \multicolumn{2}{|c|}{$\begin{array}{c}l t_{i p} \\
(\mathrm{day})\end{array}$} & \multirow{2}{*}{$\begin{array}{l}\text { Vehicle } \\
\text { capacity } \\
\text { (kg) }\end{array}$} \\
\hline & 1 & 2 & 1 & 2 & 1 & 2 & 1 & 2 & 1 & 2 & \\
\hline 1 & 300 & 300 & 200 & 200 & 5 & 5 & 3 & 3 & 0.25 & 0.25 & \multirow{2}{*}{30} \\
\hline 2 & 200 & 200 & 100 & 100 & 5 & 5 & 3 & 3 & 0.25 & 0.25 & \\
\hline
\end{tabular}

Table 3. Data used in UCC $j$

\begin{tabular}{|c|c|c|c|c|c|c|c|c|c|}
\hline \multirow{2}{*}{$\begin{array}{l}\text { Province of } \\
\text { supplier/product }\end{array}$} & \multicolumn{2}{|c|}{$\begin{array}{l}\text { Capacity } \\
(\mathrm{Kg} / \text { day })\end{array}$} & \multicolumn{2}{|c|}{$\begin{array}{c}a_{i p} \\
(\mathbf{R p} / \text { order })\end{array}$} & \multicolumn{2}{|c|}{$\begin{array}{c}\boldsymbol{h}_{i p} \\
(\mathrm{Rp} / \mathrm{kg} / \text { period })\end{array}$} & \multicolumn{2}{|c|}{$\begin{array}{c}1 t_{i p} \\
(\mathrm{day})\end{array}$} & \multirow{2}{*}{$\begin{array}{l}\text { Truck capacity } \\
\text { (kg) }\end{array}$} \\
\hline & 1 & 2 & 1 & 2 & 1 & 2 & 1 & 2 & \\
\hline 1 & 0 & 60 & 12 & 6 & 8 & 4 & 0.5 & 0.25 & \multirow{2}{*}{60} \\
\hline 2 & 100 & 60 & 6 & 6 & 4 & 4 & 0.25 & 0.25 & \\
\hline
\end{tabular}

Table 4. Data used in province of supplier $i$

\begin{tabular}{|c|c|c|c|c|c|c|c|c|c|c|c|c|}
\hline \multirow[b]{2}{*}{ Node } & \multicolumn{6}{|c|}{ Distance link $1(\mathrm{~km})$} & \multicolumn{6}{|c|}{ Distance link $2(\mathrm{~km})$} \\
\hline & 1 & 2 & 3 & 4 & 5 & 6 & 1 & 2 & 3 & 4 & 5 & 6 \\
\hline 1 & 0 & 3 & 2 & 1 & 5 & 4 & 0 & 2 & 3 & 2 & 4 & 3 \\
\hline 2 & 3 & 0 & 4 & 2 & 3 & 1 & 2 & 0 & 5 & 1 & 4 & 2 \\
\hline 3 & 2 & 4 & 0 & 5 & 2 & 1 & 3 & 5 & 0 & 4 & 1 & 2 \\
\hline 4 & 1 & 2 & 5 & 0 & 2 & 1 & 2 & 1 & 4 & 0 & 3 & 2 \\
\hline 5 & 5 & 3 & 2 & 2 & 0 & 4 & 4 & 4 & 1 & 3 & 0 & 5 \\
\hline 6 & 4 & 1 & 1 & 1 & 4 & 0 & 3 & 2 & 2 & 2 & 5 & 0 \\
\hline
\end{tabular}

Table 5. Distance between nodes

\begin{tabular}{|c|c|c|c|c|c|c|c|c|c|c|c|c|}
\hline \multirow[b]{2}{*}{ Node } & \multicolumn{6}{|c|}{ Time loss link 1 (hour) } & \multicolumn{6}{|c|}{ Time loss link 2 (hour) } \\
\hline & 1 & 2 & 3 & 4 & 5 & 6 & 1 & 2 & 3 & 4 & 5 & 6 \\
\hline 1 & 0 & 3 & 4 & 5 & 1 & 2 & 0 & 4 & 3 & 4 & 2 & 3 \\
\hline 2 & 3 & 0 & 2 & 4 & 3 & 5 & 4 & 0 & 1 & 5 & 2 & 4 \\
\hline 3 & 4 & 2 & 0 & 1 & 4 & 5 & 3 & 1 & 0 & 2 & 5 & 4 \\
\hline 4 & 5 & 4 & 1 & 0 & 4 & 5 & 4 & 5 & 2 & 0 & 3 & 4 \\
\hline 5 & 1 & 3 & 4 & 4 & 0 & 2 & 2 & 2 & 5 & 3 & 0 & 1 \\
\hline 6 & 2 & 5 & 5 & 5 & 2 & 0 & 3 & 4 & 4 & 4 & 1 & 0 \\
\hline
\end{tabular}

Table 6. Time loss between nodes

Opened UCC is UCC 1 with capacity level 2. UCC 1 is supplied by province of supplier 1 and 2 . Province of supplier 1 only supplies product 1 because the product that is available at province of supplier 1 is only product 1 . Province of supplier 2 can supply product 1 and product 2 because on province of supplier 2 has both of the products. Opened UCC 1 serves all traditional markets by forming vehicle routes. There are 2 tours of vehicle routes established to serve the traditional markets. Tour 1 consists of UCC 1 - TM 3 - TM 4 - UCC 1. From UCC 1 to TM 3, the vehicle traverses link 1, from TM 3 to TM 4, the vehicle traverses link 1, and from TM 4 to UCC 1 traversed link is link 2. Tour 2 consists of UCC 1 - TM 5 - TM 6 - UCC 1. From UCC 1 to TM 5, the traversed link is link 1, from TM 5 to TM 6, the traversed link is link 2, and from TM 6 to UCC 1, the traversed link is link 1. 


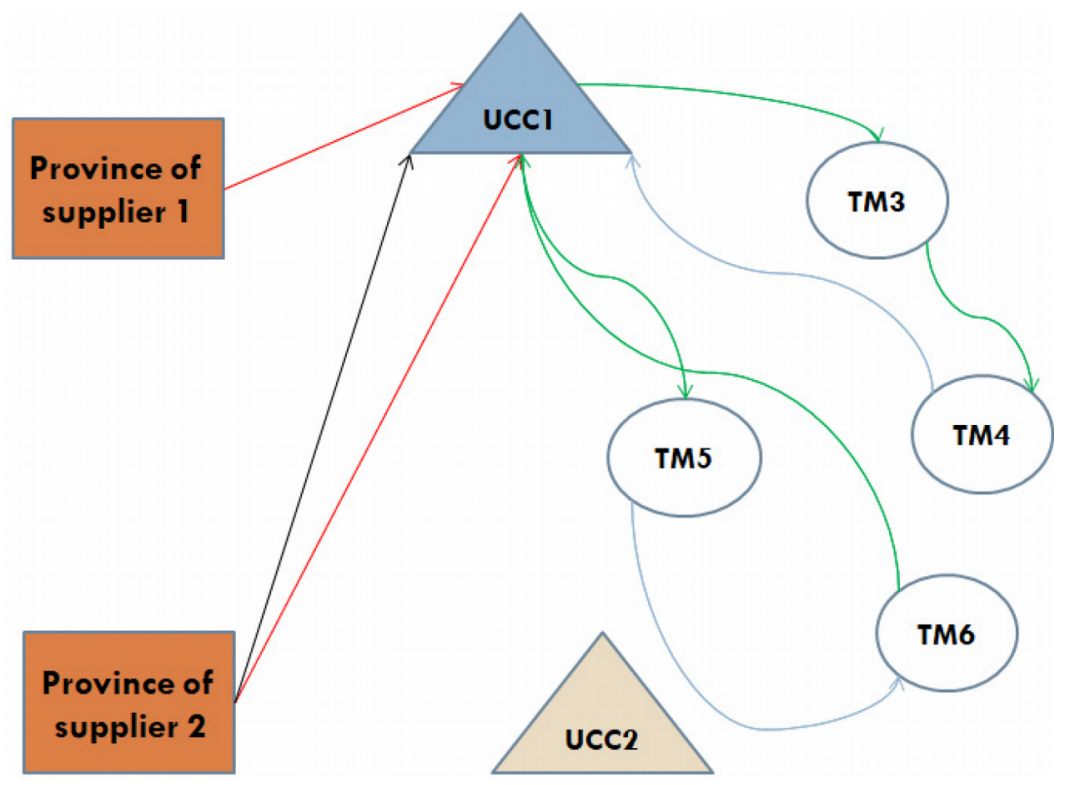

Figure 4. Solution of the illustration of system studied

Comparison for method of heuristic and method of optimal can be seen in Table 7. The efficiency for method of heuristic is $3.1 \%$ on average.

\begin{tabular}{|c|c|c|c|c|c|c|c|c|}
\hline \multirow[b]{2}{*}{ No. } & \multirow[b]{2}{*}{$\begin{array}{l}\text { \# province } \\
\text { of supplier }\end{array}$} & \multirow[b]{2}{*}{ \# UCC } & \multirow[b]{2}{*}{$\begin{array}{l}\text { \# traditional } \\
\text { markets }\end{array}$} & \multicolumn{2}{|c|}{ Method of optimal } & \multicolumn{2}{|c|}{ Method of heuristic } & \multirow{2}{*}{ 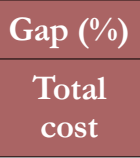 } \\
\hline & & & & $\begin{array}{l}\text { Total cost } \\
\text { (Rp/day) }\end{array}$ & CPU times (s) & $\begin{array}{l}\text { Total cost } \\
\text { (Rp/day) }\end{array}$ & $\begin{array}{c}\text { CPU } \\
\text { times (s) }\end{array}$ & \\
\hline 1 & 2 & 2 & 4 & 1938 & 172800 limit & 2003 & 23 & 3.3 \\
\hline 2 & 3 & 2 & 4 & 2183 & 172800 limit & 2215 & 28 & 1.5 \\
\hline 3 & 2 & 3 & 4 & $\mathrm{NA}$ & 172800 limit & 1961 & 30 & \\
\hline 4 & 3 & 3 & 4 & 2162 & 172800 limit & 2258 & 21 & 4.5 \\
\hline 5 & 2 & 2 & 5 & 2414 & 172800 limit & 2413 & 23 & 0.0 \\
\hline 6 & 3 & 2 & 5 & 2591 & 23302 & 2759 & 25 & 6.5 \\
\hline 7 & 2 & 3 & 5 & $\mathrm{NA}$ & 172800 limit & 2447 & 31 & \\
\hline 8 & 3 & 3 & 5 & NA & 172800 limit & 2783 & 27 & \\
\hline \multicolumn{8}{|c|}{ Average } & 3.1 \\
\hline
\end{tabular}

Table 7. Comparison for both solution method

\section{Application in City of Jakarta}

Method of heuristic for the LIRP model is applied in city of Jakarta. There are two links considered. Link 1 is road with the longest distance and link 2 is road with the shortest distance. Illustration of link 1 and link 2 can be seen in Figure 5. Figure 5 is location map of Cempaka Putih Market and Gembrong Inpres Market which are connected by 2 links. Link 1 is taken through Jl. Letjen Suprapto and Jl. Pangkalan Asem Raya. Link 2 is taken through Jl. Cempaka Putih Barat III and Jl. Cempaka Raya.

There are 12 province of suppliers, 4 potential UCCs, 165 traditional markets, and 10 products in the food supply chain system of Jakarta. For traditional markets, some of the results are given in Table 8. 


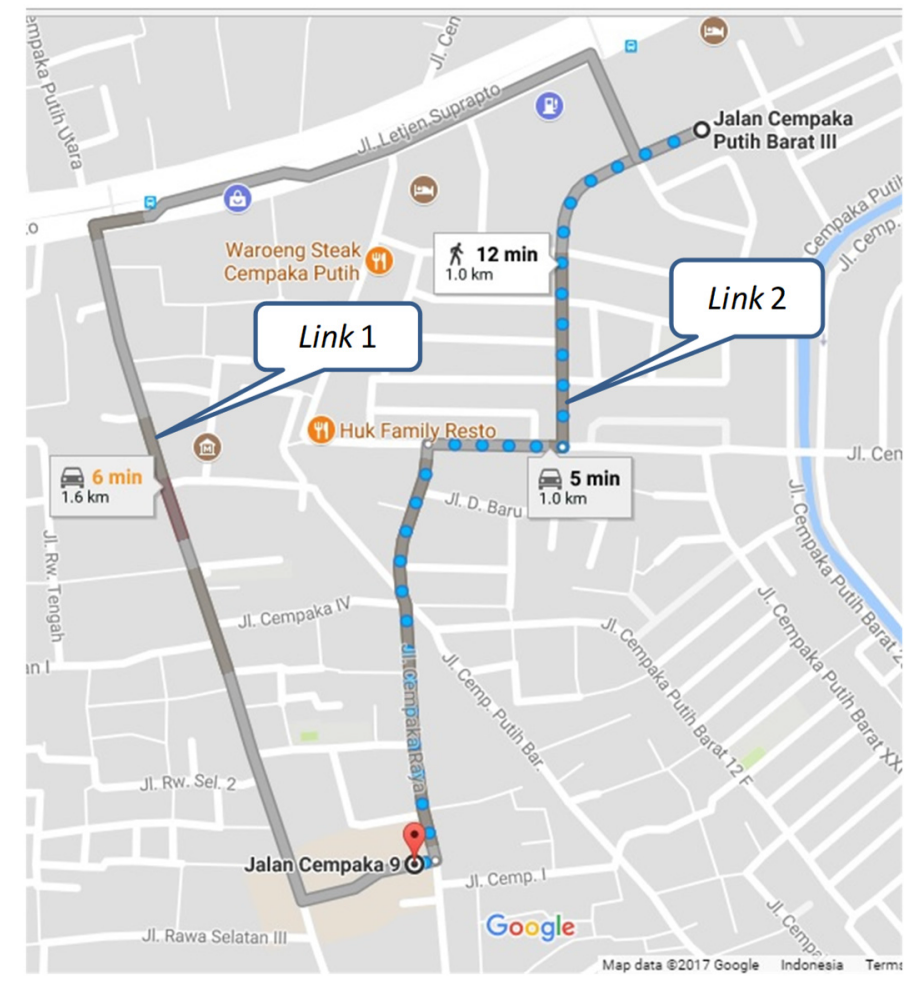

Figure 5. Location map and connecting links

\begin{tabular}{|c|c|c|c|c|c|c|c|c|}
\hline \multirow{2}{*}{$\begin{array}{l}\text { Retail } \\
\text { market }\end{array}$} & \multicolumn{2}{|c|}{ Demands (kg/day) } & \multicolumn{2}{|c|}{ Lot size $(\mathrm{kg})$} & \multicolumn{2}{|c|}{ Safety stock (kg) } & \multicolumn{2}{|c|}{ Order frequency } \\
\hline & Product 2 & Product 7 & Product 2 & Product 7 & Product 2 & Product 7 & Product 2 & Product 7 \\
\hline 1 & 96 & 542 & 38.4 & 217.0 & 6.33 & 43.11 & 1 & 1 \\
\hline 2 & 96 & 542 & 38.4 & 217.0 & 6.79 & 42.36 & 1 & 1 \\
\hline 3 & 79 & 447 & 31.6 & 178.9 & 6.23 & 36.16 & 1 & 1 \\
\hline 4 & 79 & 447 & 31.6 & 178.9 & 5.84 & 33.33 & 1 & 1 \\
\hline 5 & 26 & 147 & 10.4 & 58.7 & 2.05 & 9.93 & 1 & 1 \\
\hline 6 & 26 & 147 & 10.4 & 58.7 & 1.86 & 11.87 & 1 & 1 \\
\hline 7 & 26 & 147 & 10.4 & 58.7 & 1.78 & 10.28 & 1 & 1 \\
\hline 8 & 26 & 147 & 10.4 & 58.7 & 1.99 & 10.94 & 1 & 1 \\
\hline 9 & 58 & 325 & 23.0 & 130.2 & 4.07 & 25.64 & 1 & 1 \\
\hline 10 & 58 & 325 & 23.0 & 130.2 & 4.07 & 24.25 & 1 & 1 \\
\hline 11 & 40 & 225 & 15.9 & 90.1 & 3.05 & 15.23 & 1 & 1 \\
\hline 12 & 40 & 225 & 15.9 & 90.1 & 2.63 & 16.95 & 1 & 1 \\
\hline 13 & 40 & 225 & 15.9 & 90.1 & 2.85 & 15.41 & 1 & 1 \\
\hline 14 & 40 & 225 & 15.9 & 90.1 & 3.14 & 18.05 & 1 & 1 \\
\hline 15 & 9 & 53 & 3.7 & 21.2 & 0.73 & 4.09 & 1 & 1 \\
\hline 16 & 9 & 53 & 3.7 & 21.2 & 0.63 & 4.17 & 1 & 1 \\
\hline 17 & 9 & 53 & 3.7 & 21.2 & 0.72 & 3.98 & 1 & 1 \\
\hline 18 & 9 & 53 & 3.7 & 21.2 & 0.65 & 4.24 & 1 & 1 \\
\hline 19 & 9 & 53 & 3.7 & 21.2 & 0.62 & 3.70 & 1 & 1 \\
\hline 20 & 9 & 53 & 3.7 & 21.2 & 0.67 & 3.78 & 1 & 1 \\
\hline
\end{tabular}




\begin{tabular}{|c|c|c|c|c|c|c|c|c|}
\hline \multirow{2}{*}{$\begin{array}{l}\text { Retail } \\
\text { market }\end{array}$} & \multicolumn{2}{|c|}{ Demands (kg/day) } & \multicolumn{2}{|c|}{ Lot size (kg) } & \multicolumn{2}{|c|}{ Safety stock (kg) } & \multicolumn{2}{|c|}{ Order frequency } \\
\hline & Product 2 & Product 7 & Product 2 & Product 7 & Product 2 & Product 7 & Product 2 & Product 7 \\
\hline 21 & 9 & 53 & 3.7 & 21.2 & 0.62 & 3.86 & 1 & 1 \\
\hline 22 & 9 & 53 & 3.7 & 21.2 & 0.66 & 3.58 & 1 & 1 \\
\hline 23 & 156 & 881 & 62.3 & 352.4 & 12.49 & 71.21 & 1 & 1 \\
\hline 24 & 27 & 155 & 11.0 & 62.2 & 2.07 & 11.47 & 1 & 1 \\
\hline 25 & 27 & 155 & 11.0 & 62.2 & 1.90 & 11.12 & 1 & 1 \\
\hline 26 & 27 & 155 & 11.0 & 62.2 & 1.88 & 11.70 & 1 & 1 \\
\hline 27 & 27 & 155 & 11.0 & 62.2 & 2.05 & 10.39 & 1 & 1 \\
\hline 28 & 36 & 204 & 14.4 & 81.5 & 2.84 & 14.43 & 1 & 1 \\
\hline 29 & 36 & 204 & 14.4 & 81.5 & 2.63 & 14.27 & 1 & 1 \\
\hline 30 & 96 & 542 & 43.5 & 245.7 & 7.94 & 46.67 & 1 & 1 \\
\hline 31 & 96 & 542 & 28.1 & 159.1 & 5.24 & 28.15 & 1 & 1 \\
\hline 32 & 79 & 447 & 28.1 & 159.1 & 4.76 & 27.84 & 1 & 1 \\
\hline 33 & 79 & 447 & 28.1 & 159.1 & 5.54 & 30.78 & 1 & 1 \\
\hline$\ldots$ & $\ldots$ & $\ldots$ & $\ldots$ & $\ldots$ & $\ldots$ & $\ldots$ & $\ldots$ & $\ldots$ \\
\hline 154 & 41 & 229 & 9.1 & 51.6 & 1.72 & 9.70 & 1 & 1 \\
\hline 155 & 41 & 229 & 9.1 & 51.6 & 1.78 & 9.61 & 1 & 1 \\
\hline 156 & 41 & 229 & 9.1 & 51.6 & 1.67 & 9.98 & 1 & 1 \\
\hline 157 & 41 & 229 & 9.1 & 51.6 & 1.67 & 10.34 & 1 & 1 \\
\hline 158 & 23 & 129 & 9.1 & 51.6 & 1.60 & 9.80 & 1 & 1 \\
\hline 159 & 23 & 129 & 9.1 & 51.6 & 1.75 & 10.16 & 1 & 1 \\
\hline 160 & 23 & 129 & 9.1 & 51.6 & 1.67 & 9.51 & 1 & 1 \\
\hline 161 & 23 & 129 & 10.9 & 61.8 & 2.12 & 10.58 & 1 & 1 \\
\hline 162 & 23 & 129 & 10.9 & 61.8 & 1.89 & 10.46 & 1 & 1 \\
\hline 163 & 23 & 129 & 10.9 & 61.8 & 1.98 & 12.29 & 1 & 1 \\
\hline 164 & 23 & 129 & 42.1 & 238.1 & 7.45 & 46.90 & 1 & 1 \\
\hline 165 & 27 & 155 & 42.1 & 238.1 & 8.51 & 45.65 & 1 & 1 \\
\hline Total & 5301 & 29976 & 2120 & 11991 & 392 & 2227 & & \\
\hline
\end{tabular}

Table 8. Traditional markets' results

For UCCs, some of the results are given in Table 9 and Table 10.

\begin{tabular}{|c|c|c|c|c|c|c|}
\hline \multirow[b]{2}{*}{ UCC } & \multicolumn{2}{|c|}{ Demands (kg/day) } & \multicolumn{2}{|c|}{ Lot size (kg) } & \multicolumn{2}{|c|}{ Order frequency } \\
\hline & Product 2 & Product 7 & Product 2 & Product 7 & Product 2 & Product 7 \\
\hline 1 & 1075 & 6078 & 430 & 2431 & 1 & 1 \\
\hline 2 & 1265 & 7156 & 506 & 2862 & 1 & 1 \\
\hline 3 & 1505 & 8511 & 602 & 3405 & 1 & 1 \\
\hline 4 & 1456 & 8231 & 582 & 3293 & 1 & 1 \\
\hline Total & 5301 & 29976 & 2120 & 11991 & & \\
\hline
\end{tabular}

Table 9. UCCs' results (1) 


\begin{tabular}{|c|c|c|c|c|c|c|c|c|c|c|c|c|c|c|c|}
\hline UCC & $\begin{array}{c}\text { Vehicle } \\
\text { capacity (Kg) }\end{array}$ & $\begin{array}{l}\text { Vehicles } \\
\text { (Unit) }\end{array}$ & \multicolumn{13}{|c|}{ Route of the vehicles } \\
\hline \multirow{4}{*}{1} & \multirow{4}{*}{8000} & 1 & 1 & 14 & 16 & 17 & 13 & 9 & 8 & 1 & & & & & \\
\hline & & 2 & 1 & 7 & 41 & 36 & 39 & 1 & & & & & & & \\
\hline & & 3 & 1 & 34 & 6 & 5 & 1 & & & & & & & & \\
\hline & & 4 & 1 & 27 & 1 & & & & & & & & & & \\
\hline \multirow{4}{*}{2} & \multirow{4}{*}{8000} & 5 & 2 & 138 & 137 & 142 & 135 & 140 & 141 & 136 & 129 & 130 & 134 & 2 & \\
\hline & & 6 & 2 & 108 & 109 & 133 & 112 & 114 & 110 & 118 & 2 & & & & \\
\hline & & 7 & 2 & 111 & 113 & 115 & 15 & 22 & 23 & 26 & 31 & 30 & 28 & 40 & 2 \\
\hline & & 8 & 2 & 139 & 119 & 120 & 121 & 149 & 117 & 116 & 2 & & & & \\
\hline \multirow{5}{*}{3} & \multirow{5}{*}{8000} & 9 & 3 & $\begin{array}{l}65 \\
3\end{array}$ & 60 & 61 & 58 & 63 & 53 & 57 & 59 & 42 & 45 & 49 & $44 \quad 47$ \\
\hline & & 10 & 3 & 73 & 71 & 69 & 66 & 70 & 51 & 54 & 55 & 52 & 56 & 50 & 623 \\
\hline & & 11 & 3 & 165 & 167 & 166 & 161 & 168 & 169 & 3 & & & & & \\
\hline & & 12 & 3 & $\begin{array}{l}64 \\
20 \\
\end{array}$ & $\begin{array}{l}96 \\
19 \\
\end{array}$ & $\begin{array}{l}92 \\
24 \\
\end{array}$ & $\begin{array}{l}94 \\
18 \\
\end{array}$ & $\begin{array}{l}93 \\
10 \\
\end{array}$ & $\begin{array}{l}90 \\
11 \\
\end{array}$ & $\begin{array}{l}91 \\
12 \\
\end{array}$ & $\begin{array}{l}88 \\
3 \\
\end{array}$ & 83 & 82 & 29 & $25 \quad 21$ \\
\hline & & 13 & 3 & 35 & 38 & 37 & 3 & & & & & & & & \\
\hline \multirow{5}{*}{4} & \multirow{5}{*}{8000} & 14 & 4 & 154 & 155 & 153 & 156 & 157 & 159 & 163 & 160 & 162 & 164 & 158 & 4 \\
\hline & & 15 & 4 & $\begin{array}{l}150 \\
151\end{array}$ & $\begin{array}{l}95 \\
152\end{array}$ & $\begin{array}{l}102 \\
146\end{array}$ & $\begin{array}{l}103 \\
4\end{array}$ & 104 & 125 & 126 & 124 & 122 & 148 & 123 & 127 \\
\hline & & 16 & 4 & $\begin{array}{l}100 \\
43\end{array}$ & $\begin{array}{l}101 \\
48\end{array}$ & $\begin{array}{l}98 \\
46 \\
\end{array}$ & $\begin{array}{l}99 \\
4\end{array}$ & 86 & 97 & 89 & 87 & 75 & 74 & 68 & $72 \quad 67$ \\
\hline & & 17 & 4 & $\begin{array}{l}85 \\
128 \\
\end{array}$ & $\begin{array}{l}84 \\
131 \\
\end{array}$ & $\begin{array}{l}107 \\
4\end{array}$ & 106 & 105 & 77 & 80 & 76 & 79 & 78 & 81 & $33 \quad 32$ \\
\hline & & 18 & 4 & 145 & 144 & 147 & 132 & 143 & 4 & & & & & & \\
\hline
\end{tabular}

Table 10. UCCs' results (2)

Traversed links for every vehicle route is given in Table 11.

\begin{tabular}{|c|c|c|c|c|c|c|c|c|c|c|c|c|c|c|c|c|c|c|c|}
\hline No. & \multicolumn{10}{|c|}{ Route of the vehicles } & \multicolumn{9}{|c|}{ Traversed links } \\
\hline 1 & 1 & 14 & 16 & 17 & 13 & 9 & 8 & 1 & & & 1 & 2 & 2 & 1 & 2 & 2 & 1 & & \\
\hline 2 & 1 & 7 & 41 & 36 & 39 & 1 & & & & & 1 & 1 & 1 & 2 & 1 & & & & \\
\hline 3 & 1 & 34 & 6 & 5 & 1 & & & & & & 1 & 2 & 2 & 1 & & & & & \\
\hline 4 & 1 & 27 & 1 & & & & & & & & 1 & 1 & & & & & & & \\
\hline 5 & 2 & $\begin{array}{l}138 \\
134\end{array}$ & $\begin{array}{l}137 \\
2\end{array}$ & 142 & 135 & 140 & 141 & 136 & 129 & 130 & 1 & $\begin{array}{l}1 \\
1\end{array}$ & $\begin{array}{l}1 \\
1\end{array}$ & 1 & 1 & 1 & 2 & 2 & 1 \\
\hline 6 & 2 & 108 & 109 & 133 & 112 & 114 & 110 & 118 & 2 & & 1 & 1 & 2 & 2 & 1 & 1 & 2 & 1 & \\
\hline 7 & 2 & $\begin{array}{l}111 \\
28\end{array}$ & $\begin{array}{l}113 \\
40\end{array}$ & $\begin{array}{l}115 \\
2\end{array}$ & 15 & 22 & 23 & 26 & 31 & 30 & 1 & 2 & $\begin{array}{l}1 \\
2 \\
\end{array}$ & $\begin{array}{l}1 \\
1 \\
\end{array}$ & 2 & 1 & 1 & 2 & 1 \\
\hline 8 & 2 & 139 & 119 & 120 & 121 & 149 & 117 & 116 & 2 & & 1 & 2 & 1 & 2 & 2 & 2 & 2 & 1 & \\
\hline 9 & 3 & $\begin{array}{l}65 \\
45\end{array}$ & $\begin{array}{l}60 \\
49\end{array}$ & $\begin{array}{l}61 \\
44\end{array}$ & $\begin{array}{l}58 \\
47\end{array}$ & $\begin{array}{l}63 \\
3\end{array}$ & 53 & 57 & 59 & 42 & 1 & 1 & $\begin{array}{l}1 \\
1\end{array}$ & $\begin{array}{l}2 \\
1\end{array}$ & $\begin{array}{l}1 \\
2\end{array}$ & $\begin{array}{l}2 \\
1\end{array}$ & 1 & 1 & 1 \\
\hline
\end{tabular}




\begin{tabular}{|c|c|c|c|c|c|c|c|c|c|c|c|c|c|c|c|c|c|c|c|}
\hline No. & \multicolumn{10}{|c|}{ Route of the vehicles } & \multicolumn{9}{|c|}{ Traversed links } \\
\hline 10 & 3 & $\begin{array}{l}73 \\
56\end{array}$ & $\begin{array}{l}71 \\
50\end{array}$ & $\begin{array}{l}69 \\
62\end{array}$ & $\begin{array}{l}66 \\
3\end{array}$ & 70 & 51 & 54 & 55 & 52 & 1 & $\begin{array}{l}2 \\
1\end{array}$ & $\begin{array}{l}1 \\
1\end{array}$ & $\begin{array}{l}1 \\
2\end{array}$ & $\begin{array}{l}1 \\
1\end{array}$ & 1 & 2 & 2 & 1 \\
\hline 11 & 3 & 165 & 167 & 166 & 161 & 168 & 169 & 3 & & & 1 & 1 & 1 & 2 & 2 & 1 & 1 & & \\
\hline 12 & 3 & $\begin{array}{l}64 \\
82 \\
11\end{array}$ & $\begin{array}{l}96 \\
29 \\
12\end{array}$ & $\begin{array}{l}92 \\
25 \\
3\end{array}$ & $\begin{array}{l}94 \\
21\end{array}$ & $\begin{array}{l}93 \\
20\end{array}$ & $\begin{array}{l}90 \\
19\end{array}$ & $\begin{array}{l}91 \\
24\end{array}$ & $\begin{array}{l}88 \\
18\end{array}$ & $\begin{array}{l}83 \\
10\end{array}$ & 1 & $\begin{array}{l}2 \\
1 \\
2\end{array}$ & $\begin{array}{l}1 \\
2 \\
1\end{array}$ & $\begin{array}{l}1 \\
2 \\
1\end{array}$ & $\begin{array}{l}1 \\
2 \\
1\end{array}$ & $\begin{array}{l}1 \\
2\end{array}$ & $\begin{array}{l}1 \\
1\end{array}$ & $\begin{array}{l}1 \\
1\end{array}$ & $\begin{array}{l}1 \\
1\end{array}$ \\
\hline 13 & 3 & 35 & 38 & 37 & 3 & & & & & & 1 & 2 & 1 & 1 & & & & & \\
\hline 14 & 4 & $\begin{array}{l}154 \\
164\end{array}$ & $\begin{array}{l}155 \\
158\end{array}$ & $\begin{array}{l}153 \\
4\end{array}$ & 156 & 157 & 159 & 163 & 160 & 162 & 1 & $\begin{array}{l}1 \\
1\end{array}$ & $\begin{array}{l}2 \\
1\end{array}$ & $\begin{array}{l}1 \\
1\end{array}$ & 1 & 2 & 2 & 1 & 2 \\
\hline 15 & 4 & $\begin{array}{l}150 \\
148\end{array}$ & $\begin{array}{l}95 \\
123\end{array}$ & $\begin{array}{l}102 \\
127\end{array}$ & $\begin{array}{l}103 \\
151\end{array}$ & $\begin{array}{l}104 \\
152\end{array}$ & $\begin{array}{l}125 \\
146\end{array}$ & $\begin{array}{l}126 \\
4\end{array}$ & 124 & 122 & 1 & $\begin{array}{l}2 \\
1\end{array}$ & $\begin{array}{l}1 \\
1\end{array}$ & $\begin{array}{l}1 \\
1\end{array}$ & $\begin{array}{l}1 \\
1\end{array}$ & $\begin{array}{l}2 \\
1\end{array}$ & $\begin{array}{l}2 \\
2\end{array}$ & 1 & 1 \\
\hline 16 & 4 & $\begin{array}{l}100 \\
74\end{array}$ & $\begin{array}{l}101 \\
68\end{array}$ & $\begin{array}{l}98 \\
72\end{array}$ & $\begin{array}{l}99 \\
67\end{array}$ & $\begin{array}{l}86 \\
43\end{array}$ & $\begin{array}{l}97 \\
48\end{array}$ & $\begin{array}{l}89 \\
46\end{array}$ & $\begin{array}{l}87 \\
4\end{array}$ & 75 & 1 & $\begin{array}{l}2 \\
1\end{array}$ & $\begin{array}{l}2 \\
2\end{array}$ & $\begin{array}{l}1 \\
1\end{array}$ & $\begin{array}{l}2 \\
1\end{array}$ & $\begin{array}{l}2 \\
1\end{array}$ & $\begin{array}{l}2 \\
2\end{array}$ & 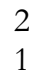 & $\begin{array}{l}1 \\
1\end{array}$ \\
\hline
\end{tabular}

Table 11. Traversed links for the vehicle routes

For province of suppliers, the results are given in Table 12.

\begin{tabular}{|c|c|c|c|c|c|}
\hline \multirow[b]{2}{*}{ Supplier } & \multirow[b]{2}{*}{ T (day) } & \multicolumn{2}{|c|}{ Demands (kg/day) } & \multicolumn{2}{|c|}{ Lot size (kg) } \\
\hline & & Product 2 & Product 7 & Product 2 & Product 7 \\
\hline 1 & \multirow{11}{*}{0.4} & 5301 & 0 & 2120 & 0 \\
\hline 2 & & 0 & 0 & 0 & 0 \\
\hline 3 & & 0 & 0 & 0 & 0 \\
\hline 4 & & 0 & 0 & 0 & 0 \\
\hline 5 & & 0 & 0 & 0 & 0 \\
\hline 7 & & 0 & 0 & 0 & 0 \\
\hline 8 & & 0 & 29976 & 0 & 11991 \\
\hline 9 & & 0 & 0 & 0 & 0 \\
\hline 10 & & 0 & 0 & 0 & 0 \\
\hline 11 & & 0 & 0 & 0 & 0 \\
\hline 12 & & 0 & 0 & 0 & 0 \\
\hline
\end{tabular}

Table 12. Province of suppliers' results

\subsection{Performance Analysis}

In Table 13, it can be seen that the new design of the food supply chain provides a more efficient total cost by $18 \%$. This is due to benefit provided by the UCCs in terms of availability which can be maintained at $95 \%$ level. The availability of the existing system only $76 \%$. As it was mentioned previously, UCCs are logistics facilities where consolidation and coordination activities are performed. In the existing supply chain system, there is no both activities. Without consolidation activity, inventory policies are carried out independently in each traditional market and in each province of supplier. In addition, without coordination activity, there is no vehicle routes formed since vehicles used to deliver goods are the vehicles originating directly from each province of supplier.

The new design also reduces the number of vehicles by $73 \%$ due to the use of vehicles together at UCCs. Moreover, with the new design of supply chain in Jakarta, there is opportunity to use environmentally friendly and 
fuel-efficient goods vehicles (green vehicles) that can be used at UCCs to deliver goods to traditional markets in urban areas.

\begin{tabular}{|c|c|c|c|}
\hline No. & Performances & New design of supply chain system & Existing supply chain system \\
\hline 1 & Total cost & Rp1,878,425,223/day & Rp2,209,950,923/day \\
\hline 2 & Availability/service level & $95 \%$ & $76 \%$ \\
\hline 3 & Number of vehicles & 39 vehicles/day & 165 vehicles/day \\
\hline
\end{tabular}

Table 13. Comparison of the performances

\section{Conclusion}

This paper has successfully developed a model of LIRP that considers multiple links to represent the road networks in cities. There is no model of LIRP that considers multiple links; therefore, this paper gives contribution in the LIRP models that were developed before. The model developed in this paper represents more realistic real systems where there are multiple road networks that connect places in urban areas.

To apply the model in a real system, which is Jakarta, this paper develops method of heuristic based on algorithm of simulated annealing. The new design resulted from the application of the model improves both the effectiveness and efficiency of Jakarta's food supply chain. Total cost reduces by $18 \%$, availability/service level increases from $76 \%$ to $95 \%$, and number of vehicles reduces by $73 \%$.

Number of links considered in the real system is 2 links which represent the longest (link 1) and the shortest distance (link 2). It can be seen from the results (Table 11) that the traversed links are not always the shortest ones. This is due to cost of congestion which also considered when deciding the vehicle routes. In cities, distance is not the only consideration to decide the traversed links. This paper shows that the distance can be short, but if the traffic is congested then the link is not traversed.

Since the average gap in terms of total cost between method of heuristic and method of optimal is $3.1 \%$, this paper also provides opportunities for future work to develop more efficient method of heuristic to solve the model in large data.

\section{Declaration of Conflicting Interests}

The authors declared no potential conflicts of interest with respect to the research, authorship, and/or publication of this article.

\section{Funding}

The authors received no financial support for the research, authorship, and/or publication of this article.

\section{References}

Ahmadi-Javid, A., \& Azad, N. (2010). Incorporating location, routing and inventory decisions in supply chain network design. Transportation Research Part E: Logistics and Transportation Review, 46(5), 582-597. https://doi.org/10.1016/j.tre.2009.06.005

Bagherinejad, J., \& Najafi-Ghobadi, S. (2019). Two Meta-heuristic Algorithms for a Capacitated Inventory-location Problem in Multi-echelon Supply Chain. International Journal of Supply and Operations Management, 6(4), 334-348. https://doi.org/10.22034/2019.4.4

Farias, K., Hadj-Hamou, K., \& Yugma, C. (2020). Model and exact solution for a two-echelon inventory routing problem. International Journal of Production Research, 0(0), 1-24. https://doi.org/10.1080/00207543.2020.1746428

Ghorbani, A., \& Akbari-Jokar, M.R. (2016). A hybrid imperialist competitive-simulated annealing algorithm for a multisource multi-product location-routing-inventory problem. Computers and Industrial Engineering, 101, 116-127. https://doi.org/10.1016/j.cie.2016.08.027 
Guerrero, W.J., Prodhon, C., Velasco, N., \& Amaya, C.A. (2013). Hybrid heuristic for the inventory location-routing problem with deterministic demand. International Journal of Production Economics, 146(1), 359-370.

https://doi.org/10.1016/j.ijpe.2013.07.025

Henderson, D., Jacobson, S.H., \& Johnson, A.W. (2003). The Theory and Practice of Simulated Annealing. In Glover, F., \& Kochenberger, G.A. (Eds.), Handbook of Metaheuristics (287-319). Springer US.

https://doi.org/10.1007/0-306-48056-5_10

Hiassat, A., Diabat, A., \& Rahwan, I. (2017). A genetic algorithm approach for location-inventory-routing problem with perishable products. Journal of Manufacturing Systems, 42, 93-103. https://doi.org/10.1016/j.jmsy.2016.10.004

Karakostas, P., Sifaleras, A., \& Georgiadis, M.C. (2020). Adaptive variable neighborhood search solution methods for the fleet size and mix pollution location-inventory-routing problem. Expert Systems with Applications, 153, 113444. https://doi.org/10.1016/j.eswa.2020.113444

Nekooghadirli, N., Tavakkoli-Moghaddam, R., Ghezavati, V.R., \& Javanmard, S. (2014). Solving a new bi-objective location-routing-inventory problem in a distribution network by meta-heuristics. Computers and Industrial Engineering, 76(1), 204-221. https://doi.org/10.1016/j.cie.2014.08.004

Rafie-Majd, Z., Pasandideh, S.H.R., \& Naderi, B. (2018). Modelling and solving the integrated inventory-location-routing problem in a multi-period and multi-perishable product supply chain with uncertainty: Lagrangian relaxation algorithm. Computers and Chemical Engineering, 109, 9-22. https://doi.org/10.1016/j.compchemeng.2017.10.013

Rahbari, M., Razavi-Hajiagha, S.H., Raeei-Dehaghi, M., Moallem, M., \& Riahi-Dorcheh, F. (2020). Modeling and solving a five-echelon location-inventory-routing problem for red meat supply chain: Case study in Iran. Kybernetes, 50(1), 66-99. https://doi.org/10.1108/K-10-2019-0652

Rayat, F., Musavi, M.M., \& Bozorgi-Amiri, A. (2017). Bi-objective reliable location-inventory-routing problem with partial backordering under disruption risks: A modified AMOSA approach. Applied Soft Computing Journal, 59, 622-643. https://doi.org/10.1016/j.asoc.2017.06.036

Sajjadi, S.R., \& Cheraghi, S.H. (2011). Multi-products location routing problem integrated with inventory under stochastic demand. International Journal of Industrial and Systems Engineering, 7(4), 454.

https://doi.org/10.1504/IJISE.2011.039670

Saragih, N.I., Bahagia, S.N., Suprayogi, \& Syabri, I. (2018). Single-tier city logistics model for multi products. International Journal of Supply Chain Management, 7(2).

Saragih, N.I., Bahagia, S.N., Suprayogi, \& Syabri, I. (2019). A heuristic method for location-inventory-routing problem in a three-echelon supply chain system. Computers and Industrial Engineering, 127.

https://doi.org/10.1016/j.cie.2018.11.026

Saragih, N.I., Bahagia, S.N., Suprayogi, \& Syabri, I. (2015). City logistics for mega city: A conceptual model (Case study: DKI Jakarta). Proceedings of the Joint International Conference on Electric Vebicular Technology and Industrial, Mechanical, Electrical and Chemical Engineering (ICEVT IMECE) (178-182).

https://doi.org/10.1109/ICEVTIMECE.2015.7496660

Tang, J., Ji, S., \& Jiang, L. (2016). The design of a sustainable location-routing-inventory model considering consumer environmental behavior. Sustainability (Switzerland), 8(3). https://doi.org/10.3390/su8030211

Taniguchi, E., Noritake, M., Yamada, T., \& Izumitani, T. (1999). Optimal size and location planning of public logistics terminals. Transportation Research Part E: Logistics and Transportation Review, 35(3), 207-222. https://doi.org/10.1016/S1366-5545(99)00009-5

Vahdani, B., Veysmoradi, D., Noori, F., \& Mansour, F. (2018). Two-stage multi-objective location-routing-inventory model for humanitarian logistics network design under uncertainty. International Journal of Disaster Risk Reduction, 27, 290-306. https://doi.org/10.1016/j.ijdrr.2017.10.015 
Zhalechian, M., Tavakkoli-Moghaddam, R., Zahiri, B., \& Mohammadi, M. (2016). Sustainable design of a closed-loop location-routing-inventory supply chain network under mixed uncertainty. Transportation Research Part E: Logistics and Transportation Review, 89, 182-214. https://doi.org/10.1016/j.tre.2016.02.011

Zhang, Y., Qi, M., Miao, L., \& Liu, E. (2014). Hybrid metaheuristic solutions to inventory location routing problem. Transportation Research Part E: Logistics and Transportation Review, 70(1), 305-323.

https://doi.org/10.1016/j.tre.2014.07.010

Journal of Industrial Engineering and Management, 2021 (www.jiem.org)

\section{() (1) $(8$}

Article's contents are provided on an Attribution-Non Commercial 4.0 Creative commons International License. Readers are allowed to copy, distribute and communicate article's contents, provided the author's and Journal of Industrial Engineering and Management's names are included. It must not be used for commercial purposes. To see the complete license contents, please visit https://creativecommons.org/licenses/by-nc/4.0/. 